\title{
"Flipped Class Model” Applied to Translation Class
}

\author{
ZHANG Jie \\ China Youth University for Political Sciences, Beijing, China
}

\begin{abstract}
With the development of computer technology, the way of language teaching has experienced great changes. In the past the methods of language teaching mainly focus on the direct method, the grammar-translation, audio-lingual, the structure approach, communicative language teaching, community language learning, task-based language learning, etc. These methods start and develop with the need and application of some theories. Now at the present time the computer is widely used in every field and the Internet is compulsory of daily life. So the ways of teaching language is changing accordingly. This paper is to analyze the new way of language teaching, the flipped class model. The first part is the general introduction of the flipped class model, and the second part is the application of the flipped class model to translation course.
\end{abstract}

Keywords: flipped class model, new computer technology, videos, translation course

\section{Introduction}

"Flipped Classroom", "inverted classroom", or flipped class model is to re-modulate the time for in and out of classroom teaching and learning. Traditional classroom teaching is that the teacher teaches and demonstrates and assigns homework in class and the students practiced after class either at home or at any spare time. Contrast to the traditional classroom teaching, learning under the flipped model classroom is more a stage of interaction, problems solving, and application of the knowledge of theories. Under the model the students have more right to decide the study procession, the time assorted to get to know the knowledge, and how long they use time for the assignment given. Under the model, the students may utilize the in-class time more efficiently, targeting at the specific objectives to get deeper understanding of the knowledge.

For the teachers they do not occupy the in-class time to explain the information, rather the information or knowledge to be grasped must be learned after class by the students themselves.

The students can watch the videoed lectures, listen to the podcast, read e-books with more functions, and talk with their classmates on line. With these kinds of learning, the students can search for retrieve and information they need.

With this model, the teachers have more time to talk with every student. Flipped model is integral of the whole education movement. It is a kind of hybrid learning, a researching learning. It overlaps with the other teaching methods, for which are all for the students to learn actively and freely and much involve in the class.

Flipped model is a new method for teaching and learning. With this method, teachers are more like the coach than a saint on the altar. It mixes the indirectly explanation and constructive learning

The points for flipped class model are as the followings: Firstly, it is how to guide the students to watch

ZHANG Jie, associate professor, master, Department of Foreign Language and Literature, China Youth University for Political Sciences. 
the videos by themselves; secondly, it is a hard job for the teachers to make many videos; thirdly, it is how to assess the teachers function in class. ${ }^{1}$

\section{History of Flipped Class Mode Abroad and at Home}

In their thesis Maureen Lage, Glenn Platt, and Michael Treglia first introduced Inverting the Classroom: A Gateway to Creating an Inclusive Learning Environment in 2000. They mentioned that they applied the model in the "introduction to economics" and the achievement with the method. But they did not propose the term flipped teaching or flipped learning (Lage, Platt, \& Treglia, 2000).

J. Wesley Bakerg published The Classroom Flip: Using Web Course Management Tools to Become the Guide by the Side at 11th International Teaching Conference in 2000.

In 2007, Jonathan Bergmann and Aaron Sams, chemistry teachers in Wood Land Park High School, Colorado, America began to use the video and PowerPoint appended sound for explanation. He updated the videos to the Internet and the absent students could use it for the lost lessons. And he tried creatively to let the students to want the videos at home and listen to the explanation. With the preparation at home, the teacher mainly answered questions and provided help for the difficult students. The model was gradually utilized in the states. But at the same time it aroused some argument and questions. ${ }^{2}$

At home some teachers have tried the new method-flipped model and it was honored the efficient classroom. Both in the higher education and in the senior or high education, even in the elementary education the educators attempt the new model. One of the top higher universities in China has several courses taken in this form. In high schools the present model was realized in the combination of guide learning and the textbooks and the exercise books. ${ }^{3}$

\section{The Characteristic of Flipped Class Mode}

At the age of Internet, students learn more through the Internet courses. It is the advanced technology that initiates the flipped classroom model. It is completely subversion to the traditional classroom based on the printing, which rouses teachers' roles, curriculum models, management models, and other changes. Beginning in the United States, "flipping class model" is a teaching organization based on information technology. It subverts the traditional classroom to teach students, focusing on students to construct knowledge and active classroom discussion and teacher's role as a guide and helper. It is in line with the view of college students' autonomous learning and cooperative learning; it also reflects the multiple roles of teachers, through improved interpersonal and collaborative activities between teachers and students in teaching activities by video teaching. The following are the clear features of flipped class model.

(1) The teaching videos are short. A common characteristic of the flipped class model is that short. Most of the videos are only a few minutes. Long videos are only more than 10 minutes. Each video is focused on a specific issue, better targeted, and easily accessible. The length of the video controls within the students' attention, in line with the characteristics of students' mental and physical development through webcast video, with multiple functions such as pause, playback, self-control, helping students study independently.

\footnotetext{
${ }^{1}$ See http://education.news.cn/2014-04/14/c_126386097_3.htm.

${ }^{2}$ See

http://baike.baidu.com/link?url=HGq1z0vwbV3Q83qpM3FXSGWiFcLs_702UB0FNnNRZwYv8ZNAj2w-OD_dzYyuH8c2bl_4C 6EaomtSou_sAO8vga\#reference-[1]-8194867-wrap.

${ }^{3}$ See http://www.zhihu.com/question/20777604.
} 
(2) The teaching videos are conveying concise information. In the flipped class model, the students are attracted by the knowledge or information in the videos. The whole screen is about the information concerned, only with the explanation. It is just like a piece of paper placed in front of the student with a correspond explanation. On the screen there is no teacher's image, no array of the classroom which may detract the students attention, especially in the self-controlled background.

(3) Reconstruction of the study process. Usually the study process is composed of two parts: The first one is that the information transfers from the teacher to the student in class and the second one is that the students absorb the knowledge and digest what is taught. The second phase is done after class at home. Because of the lack of the teachers' help after class, the students sometimes feel frustrated with the homework and possibly lose the motivation for study. But with the flipped class model the process was reconstructed. The transfer of the information is finished before class. The teacher not only provides the videos but also is accessible for the students on line. The teachers know the students difficulties beforehand, and thus efficiently help students in class discussion afterwards. It is a useful pre-class input and successful in-class discussion and communication.

(4) The convenience and swiftness of reviews and tests. After watching the videos, the students have several questions for quiz, which help the students' understanding. If the questions are found difficult to answer, they may watch the videos over again. The other advantage of the videos is to help the students to review and strengthen the knowledge provided.

\section{The Lynchpin of Flipped Class Mode in China}

The flipped class model is to be used in China and promote a Chinese curriculum and deeper teaching reform. But there are some key points to be guarded in flipped class model. The first one is to set the confidence for the educational reform. The flipped class model is to change the model in the fixed way. The second one is that the teacher has more advanced technology in the computer. The more knowledge about computer is needed. The third one is how to make the videos. And the more important is how to control the time in class. The most important is how to make the flipped class model more successful - the students understand the information, discuss actively in class, and absorb thoroughly. The fourth one is the role exchange. The teacher's traditional controlling role turns to director and the student's role becomes more outstanding. They should be more actively in class. The parents' role change urges them to accept the new study model.

\section{The Three Steps for Flipped Class Model}

As the flipped class model, there are three major steps:

(1) To create video for the class. While make the flipped class videos, the students' backgrounds and ideas should be considered;

(2) The inc-class organization is even important for the success for the whole class;

(3) The after-class strength and assessment of the class. The student's feedback and assessment are very important for the class.

\section{The Flipped Classroom Applied to Translation Class}

The paper here is to take translation as a model course to illustrate the flipped class model.

The topic will be about division and combination in translation. The division and combination are two 
translation skills to break or combine the original structures of the original language to translate the sentences in accordance the translated language. The division is to break the original one sentence to translate into two sentences. And the combination is to combine two sentences in the original sentences into one sentence.

The following are the videos for the knowledge the students should learn before class. In the videos the translation skills are explained with examples:

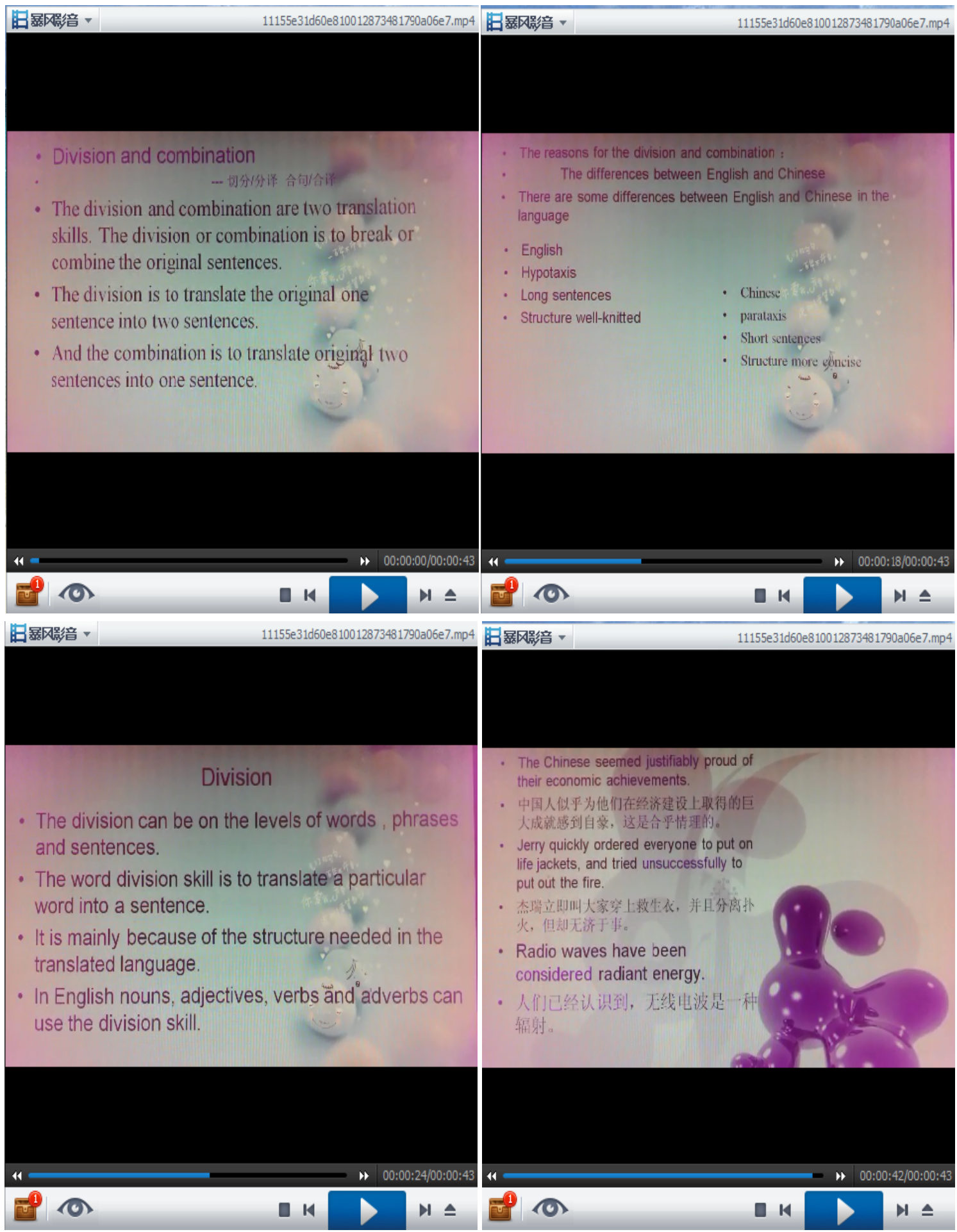




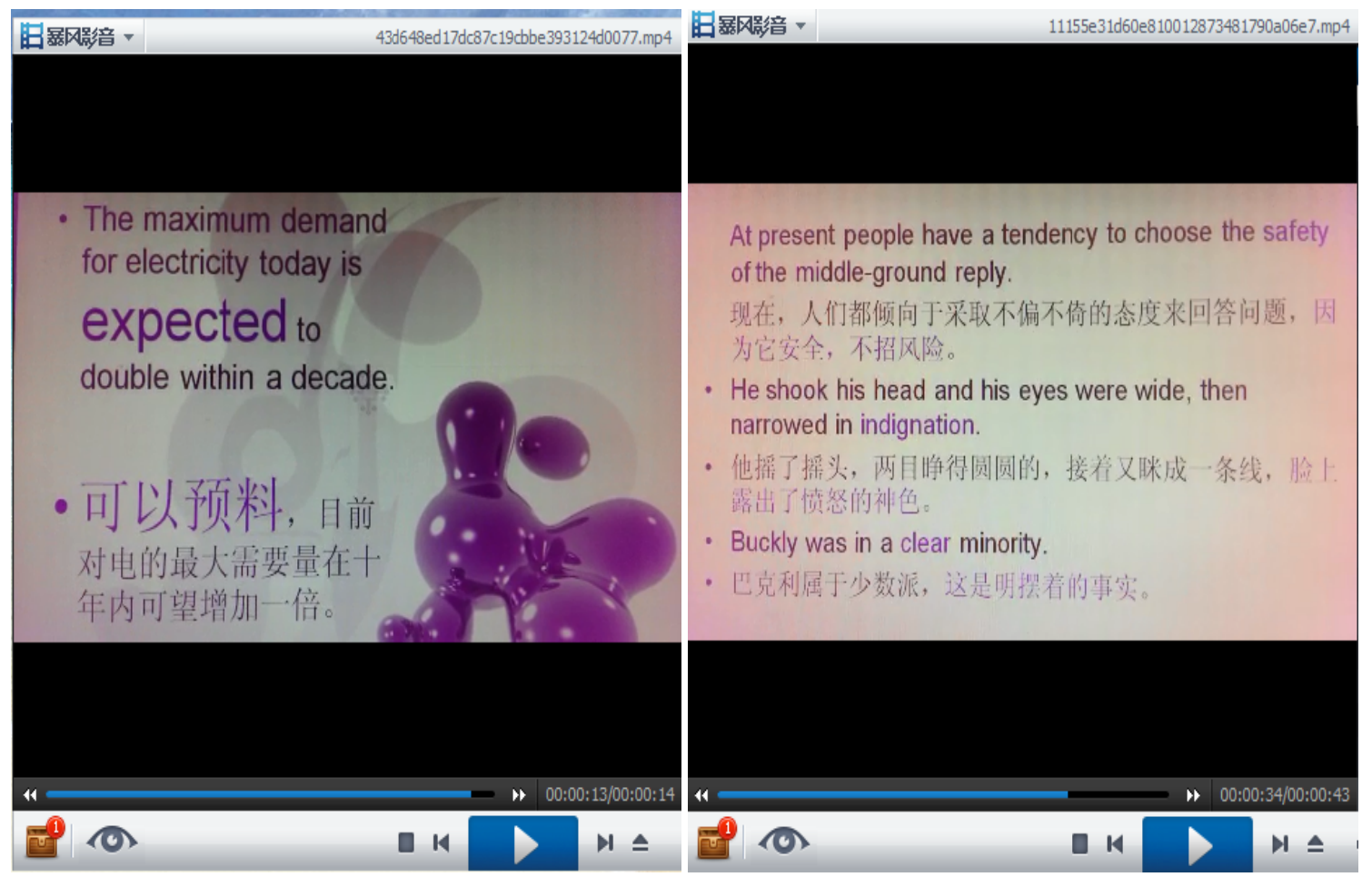

Figure 1. Illustration 1 for the translation of single word by the skill of "division".

In the videos, the first three are concerned about the theory of translation between English and Chinese. To be more exactly the first two are about the difference between English and Chinese in the sentence structure. English structures are usually with long sentences and structure well-knitted, it is hypotaxis; while Chinese structure are concise and short, a parataxis structure. And in the third picture is about the different divisions in translation. They can be the word level, the phrase level and the sentence level. That is a word can be translated into a single sentence, a phrase can be translated into a single compound or complex sentence and a sentence to a complete sentence. In the paper only the first two level, the word and phrase level are to be discussed.

The last three videos are the examples for students to learn and follow.

(1) The Chinese seemed justifiably proud of their economic achievements.

The sentence can be translated as: 中国人似乎为他们在经济建设上取得的巨大成就感到自豪, 这是 合平情理的。

(2) Jerry quickly ordered everyone to put on life jackets, and tried unsuccessfully to put out the fire.

The sentence can be translated as: 杰瑞立即叫大家穿上救生衣，扑火，但却无济于事。

(3) Radio waves have been considered radiant energy.

The sentence can be translated as: 人们已经认识到, 无线电波是一种辐射。

(4) The maximum demand for electricity today is expected to double within a decade.

The sentence can be translated as: 可以预料, 目前对电的最大需要量在十年内可望增加一倍。

(5) At present people have a tendency to choose the safety of the middle-ground reply.

The sentence can be translated as: 现在, 人们都倾向于采取不偏不倚的态度来回答问题, 因为它安全, 不招风险。

(6) He shook his head and his eyes were wide, then narrowed in indignation. 
The sentence can be translated as: 他摇了摇头, 两目睁得圆圆的, 接着又眯成一条线, 脸上露出了愤 怒的神色。

(7) Buckly was in a clear minority.

The sentence can be translated as: 巴克利属于少数派, 这是明摆着的事实。

With the video explanation, the students may notice the italic words. They are the most important words in the sentence translation. Although the italic words in each sentence only represent one part of speech, but they can be translated into a complete sentence. So in class the students can follow the example given in the videos and try to translate the sentences. For example, in class the students are assigned to translate the following sentences with attention to the italic words in each sentence.

(1) Chairman Mao might have spoken with understandable pride of his policy of "self-reliance".

The Chinese version: 毛主席谈到“自力更生”的政策时，也许有些自豪，这是可以理解的。

(2) George nodded, thankful that his wife was not the talkative kind.

The Chinese version: 乔治点点头, 他妻子不是那种絮絮叨叨的人, 对此他心存感激。

(3) That region was the most identifiable trouble place.

The Chinese version: 那地区是个麻烦的地方，这是大家很容易看出来的。

(4) The American commander, Admiral Nimitz, was understandably reluctant to join the battle.

The Chinese version：美军司令海军上将尼米兹怠于出战，这是可以理解的。

(5) I tried vainly to put the pieces together.

The Chinese version：我想把这些碎片拼在一起，可是拼不起来。

The second translation skills in the video explained is on the phrasal level. After watching the video before class, in class the students can directly try the sentence translation with the skill in the mind.

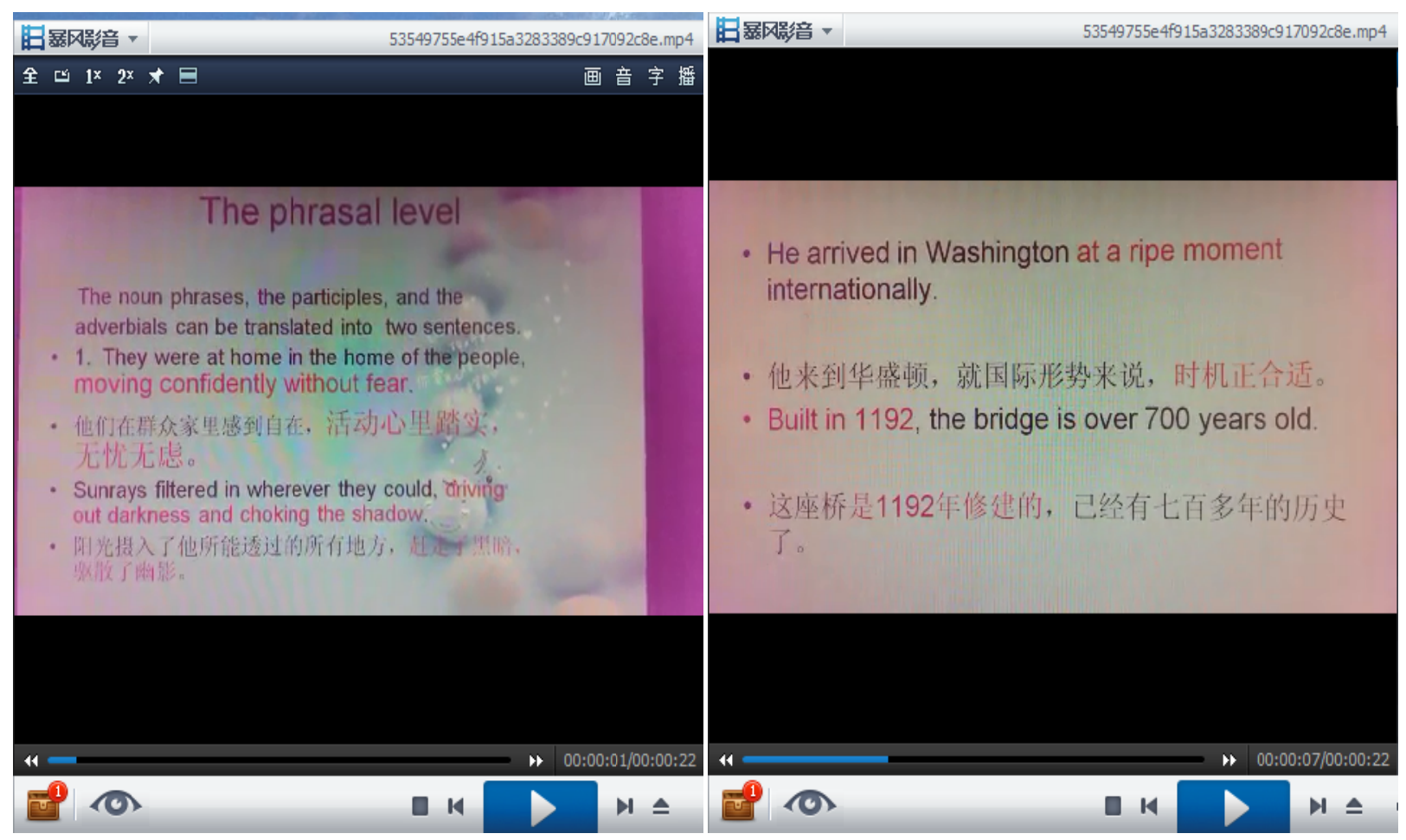




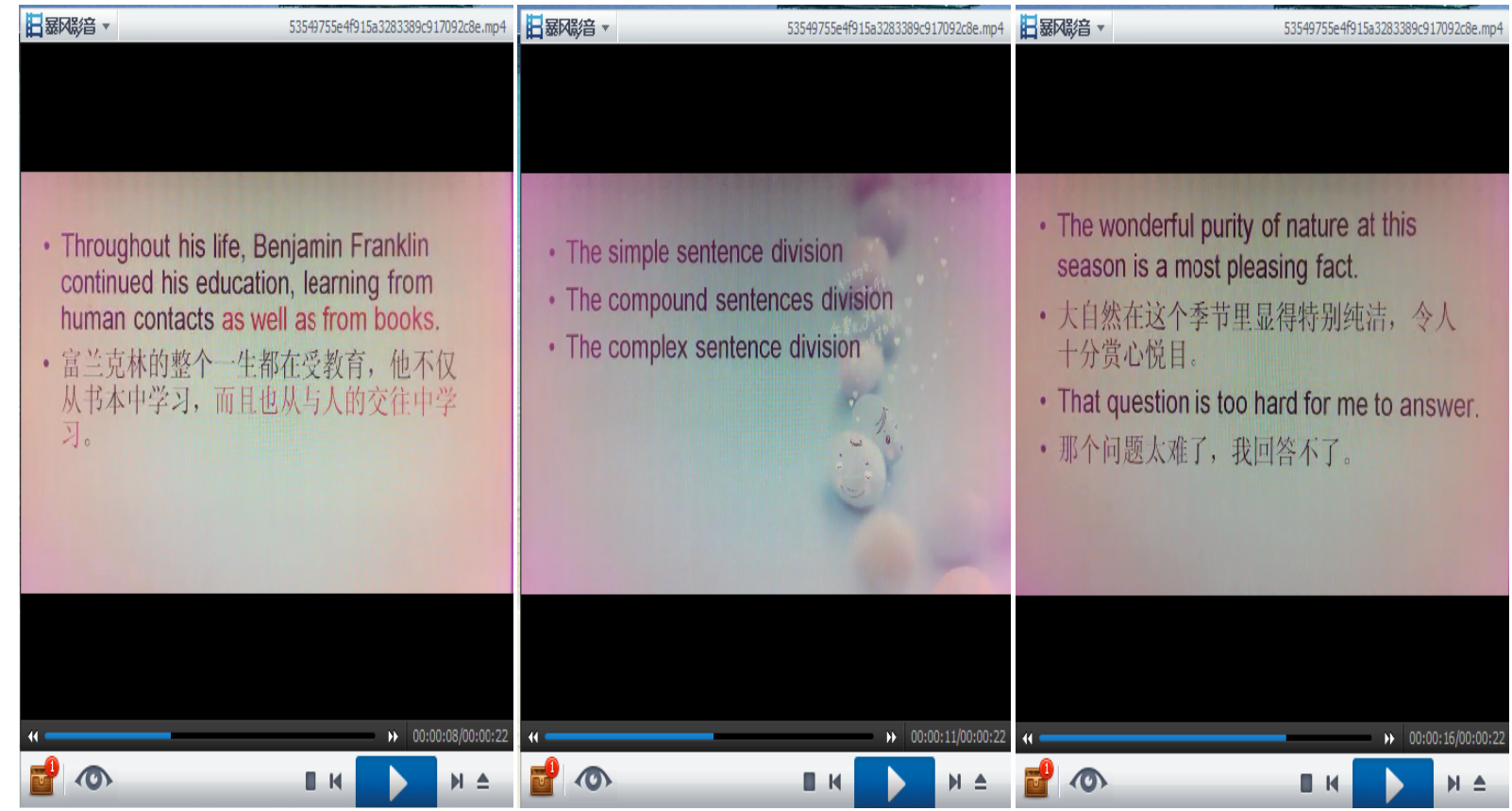

Figure 2. Illustration for skills for "the phrasal level and sentence level division"

The video explains the translation skills with the phrasal level with examples.

They are the sentences as the followings:

(1) They were at home in the home of the people, moving confidently without fear.

The Chinese version: 他们在群众家里感到自在, 活动心里踏实, 无忧无虑。

(2) Sunrays filtered in wherever they could, driving out darkness and choking the shadow.

The Chinese version: 阳光摄入了他所能透过的所有地方, 赶走了黑暗, 驱散了幽影。

(3) He arrived in Washington at a ripe moment internationally.

The Chinese version：他来到华盛顿，就国际形势来说，时机正合适。

(4) Built in 1192, the bridge is over 700 years old.

The Chinese version: 这座桥是1192年修建的，已经有七百多年的历史了。

(5) Throughout his life, Benjamin Franklin continued his education, learning from human contacts as well as from books.

The Chinese version: 富兰克林的整个一生都在受教育, 他不仅从书本中学习, 而且也从与人的交往 中学习。

With the example from the videos, the students can learn that not only single words but the phrases can be translated into a complete sentence from English into Chinese. So in class the students can translate some other sentences with the skills learned in the videos. In class teachers only need to remind the students of the division of the original sentence into two, and remind the students of the italics phrases.

(1) I wrote four books in the first three years, a record never touched before.

The Chinese version: 我头三年写了四本书，打破了以往的记录。

(2) The station chief would have to be close to the director, a member of the inner circle.

The Chinese version: 这位站长就得接近董事，因为董事是核心集团的成员。

(3) Energy can neither be created or destroyed, a universally accepted law. 
The Chinese version: 能量既不能创造也不能被消灭, 这是一条普遍公认的规律。

(4) The power increased with their number.

The Chinese version: 他们人数增加了, 力量也随之增强。

\section{The Feedback of the Videos Class Model}

After the class, the students are organized to talk about their videos learning before class and their practice in class. The students are satisfied with the experiences of watching videos before class, and try to translate some sentences afterwards. They share their leaning funs before class and are glad to perform in class. They are looking forward to have more this kind of practices.

\section{Conclusion}

With the experiences of flipped class model, the translation course is successful. The fact proves that the new method is efficient in the classroom language teaching. On the one hand, the students are active in learning with the new technological method, which helps the students to learn by themselves before class. On the other hand, this method saves a lot of in-class time, and the students have more time to practice with the classmates to share their learning experience with the peers. And more importantly with method improving the teaching and learning become more efficient. In the era of internet, the learning resources are more accessible for the students and any learners. In the long run, the flipped class can be the prior period for the flipped learning, which will be the widely used in the fragmented learning, Internet learning epic (WANG, 2015).

\section{References}

Lage, M. J., Platt, G. J., \& Treglia, M. (2000). Inverting the classroom: A gateway to creating an inclusive learning environment. The Journal of Economic Education, 31(1), 30-43.

The flipped class model teaching. (n.d.). $\quad$ Retrieved from http://baike.baidu.com/link?url=HGq1z0vwbV3Q83qpM3FXSGWiFcLs_702UB0FNnNRZwYv8ZNAj2w-OD_dzYyuH8c2 bl_4C6EaomtSou_sAO8vga\#reference-[1]-8194867-wrap

The possibility of flipped class model in China. (n.d.). Retrieved from http://www.zhihu.com/question/20777604

WANG, Z. L. (2015). The fragments and reconstruction (p. 37). Beijing: Publishing House of Electronics Industry.

Watching "Flipped Class Model": Is it a great impact on the after-school class? (2014). Retrieved from http://education.news.cn/2014-04/14/c_126386097_3.htm 